\title{
Оцінка спонтанної та індукованої лігандами TLR2 і TLR4 продукції про- і протизапальних цитокінів у хворих на абдомінальний сепсис
}

\begin{abstract}
Мета роботи: вивчити в динаміці у хворих на абдомінальний сепсис (АС) синтез про- та протизапальних цитокінів та їхній баланс для оцінки їх прогностичної значимості.

Матеріали і методи. Обстежено та прооперовано 36 хворих на абдомінальний сепсис. Усі хворі були розділені на 2 підгрупи

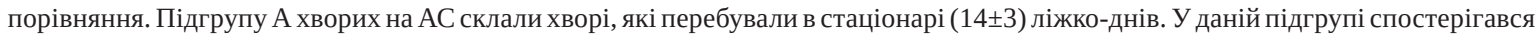

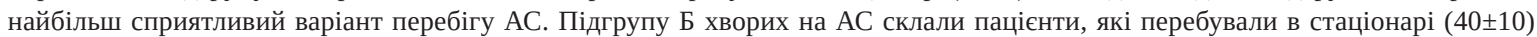
ліжко-днів. У цій групі спостерігали розвиток ряду ускладнень у перебігу АС. Групою контролю слугувала група практично здорових донорів.

Результати досліджень та їх обговорення. Вивчення в динаміці (1-10 доба) профілю цитокінів (ФНО, ІЛ-6, ІЛ-8, ІЛ-10), що продукуються мононуклеарними клітинами периферичної крові хворих на AC спонтанно і під впливом лігандів TLR,

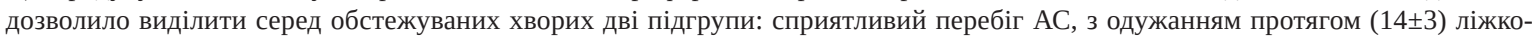
днів (спонтанна й індукована продукція IЛ-8 знижувалося до 10 доби, а індукована лігандами TLR продукція протизапального

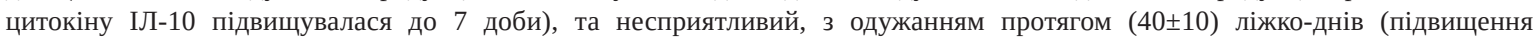
спонтанного й індукованого лігандами TLR продукції IJ-6 з 3 до 10 доби та індукованої лігандами TLR продукція цитокіну IЛ-10 до 10 доби). У хворих із сприятливим перебігом захворювання баланс прозапальних цитокінів збільшувався за рахунок ІЛ-8, а у хворих з несприятливим перебігом - ІЛ-6, що може слугувати прогностичним критерієм перебігу і наслідків АС, тоді як оцінка показників ФНО виявилася не інформативною.
\end{abstract}

Ключові слова: абдомінальний сепсис; Toll-подібні рецептори; цитокіни.

Постановка проблеми і аналіз останніх досліджень та публікацій. Відомо, що абдомінальний сепсис (АС) - тяжке захворювання, в основі якого лежить пошкодження тканин органів черевної порожнини, яке супроводжується запальною реакцією, яка набуває системного характеру та часто призводить до формування синдрому поліорганної дисфункції (СПОД) [1, 2]. Саме цим пояснюється високий рівень смертності серед таких пацієнтів, яка складає понад 10 \% вже на початковому етапі перебігу захворювання [3]. У таких випадках важливою є необхідність раннього прогнозування перебігу АС, що має значення у виборі індивідуалізованого комплексного його лікування [4].

Вивчення системи вродженого імунітету, зокрема групи Toll-подібних рецепторів (TLR), є актуальним і одним із найбільш перспективних напрямків сучасної науки. Відомо, що TLR здійснюють розпізнавання молекулярних патернів, асоційованих із різними патогенними мікроорганізмами (Pathogen-Associated Molecular Patterns РАMP), запускаючи, таким чином, ефекторні механізми вродженого імунітету [5]. Активація TLR зумовлює експресію різних генів хемокінів і прозапальних цитокінів. Окрім цитокінів, посилюється експресія молекул адгезії, протимікробних пептидів, білків гострої фази запалення, NO-синтази, циклооксигенази, що призводить до розвитку та прогресування АС [5, 6].

Однак сьогодні роль функціональної активності TLR при AC вивчена недостатньо. Окрім того, не зустрічається робіт стосовно вивчення ролі співвідношення рівнів різних прозапальних цитокінів, а також балансу про- і протизапальних цитокінів у хворих з АС. Тому, на нашу думку, не тільки рівень, а й баланс цитокінів визначає тяжкість перебігу АС.

Мета роботи: вивчити в динаміці у хворих на абдомінальний сепсис синтез про- та протизапальних цитокінів та їхній баланс для оцінки їх прогностичної значимості.

Матеріали і методи. Ми обстежили 36 хворих, які знаходились на стаціонарному лікуванні в хірургічних відділення № 1 та № 2 ОКУ “Лікарня швидкої медичної допомоги” м. Чернівці з абдомінальним сепсисом. Діагноз АС встановили відповідно до існуючих у клініці діагностичних критеріїв. Хворі розділенні на 2 підгрупи: підгрупу А (n=20) склали хворі на АС, які перебували в стаціонарі (14 \pm 3$)$ ліжко-днів. До цього часу в них спостерігалося покращення загального стану. Підгрупу Б хворих на АС склали 16 пацієнтів, які перебували в

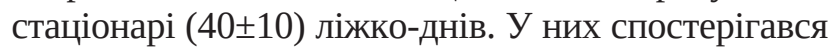
менш сприятливий перебіг захворювання. 
Контрольну групу хворих склали 30 умовно здорових донорів віком 20-40 років: 20 чоловіків і 10 жінок. Критерієм відбору умовно здорових донорів групи контролю була відсутність інфекційних та алергічних захворювань.

Всі пацієнти отримували традиційну стандартну терапію, передбачену протоколом ведення хворих на АС.

Для дослідження забирали сироватку в пробірки 3 активатором згортання і розділовим гелем (олефіновий гель). Концентрацію цитокінів в отриманій сироватці визначали методом імуноферментного аналізу (ІФА).

Суспензію мононуклеарних клітин (МНК) виділяли з периферичної крові обстежуваних хворих за методом, який базується на седиментації в односхідцевому градієнті щільності фікол-урографіну $\left(\rho=1,077 \Gamma / \mathrm{CM}^{3}\right)$.
Для стимуляції клітин лігандів TLR використовували такі стимулятори: ЛПС (E. coli 0127: B8, “Sigma”) і пептидоглікан (Staphylococcus aureus, "Sigma / Fluka”) в концентраціях 0,1 мкг/мл і 2,5 мкг/мл, відповідно. Контролем слугували MHK, культивовані в повному середовищі RPMI 1640. Супернатанти збиралися і зберігалися протягом 2-3 місяців при $-70{ }^{\circ} \mathrm{C}$. Концентрацію цитокінів в отриманих супернатантах визначали методом ІФА.

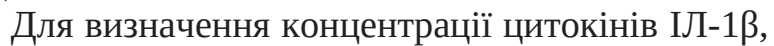
ІЛ-6, ІЛ-8, ІЛ-10, ІЛ-12 та ФНО в супернатантах культур клітин і в сироватці крові використовували комерційні набори для імуноферментного аналізу фірм Biosource i BenderMedSystems.

Нами запропоновано спосіб оцінки співвідношення цитокінів вираховували за запропонованою формулою:

$$
I J-6(\%)=\frac{I Л-6(\text { пг/мл) }}{\Phi H О \alpha(n г / м л)+I Л-6(n г / м л)+I Л-8(n г / м л)+I Л-10(n г / м л)} \times 100 \%
$$

Дані показники визначали на кожному етапі дослідження (в 1-10 добу динаміки захворювання) для спонтанної і стимульованої лігандами TLR продукції цитокінів МНК обстежуваних хворих з АС.

Статистичну обробку отриманих результатів проводили з використанням програмного пакета StatSoft Statistica 6. Для опису даних, які не підкоряються нормальному розподілу, використовували медіану, а також 25-й і 75-й процентилі. Показники, які пройшли перевірку на нормальність, описували як середнє арифметичне \pm стандартне відхилення. Для оцінки достовірності відмінностей застосовували непараметричні критерії Вілкоксона і Манна-Уїтні, а також параметричний критерій Стьюдента для зв'язаних і незв'язаних сукупностей. Різниця середніх показників вважалася достовірною, при рівні значущості <0,05.

Результати досліджень та їх обговорення. При аналізі клінічних даних пацієнтів було встановлено, що у хворих підгрупи А спостерігався сприятливий перебіг АС з більш швидким одужанням (перебування в стаціонарі склало $14 \pm 3$ ліжко-днів). У підгрупі Б зазначалося більш тривале перебування цих хворих у клініці (до 40ะ10 ліжко-днів) із менш сприятливим перебігом захворювання. Спонтанна продукція ІЛ-6 МНК периферичної крові хворих підгрупи Б дула достовірно $(\alpha=$ $0,05)$ підвищеною вже на 3 добу захворювання і склала 106 (82-240) пг / мл і 1999 (1225-9120) пг /мл в підгрупах А і Б відповідно. В інші контрольні терміни достовірних відмінностей виявлено не було. При дослідженні індукованої лігандами TLR - лі- пополісахаридом (ЛПС) продукування ІЛ-6 МНК периферичної крові хворих підгрупи А спостерігалося достовірне $(\alpha=0,05)$ підвищення цього показника вже в першу добу захворювання. Рівень індукованої продукції ІЛ-6 у них склав 13526 (810617515) пг/мл і 7787 (5119-7942) пг/мл у підгрупах А і Б відповідно. В динаміці до 3 доби захворювання у пацієнтів підгрупи Б продукція ІЛ-6 достовірно знизилася в середньому до 7899 (6392-9006) пг / мл відносно хворих підгрупи Б - в середньому до 15636 (9009-19613) пг / мл. При цьому такі відмінності зберігалися до 7 доби захворювання (рис. 1).

Медіана; відрізки: 25-75 \%

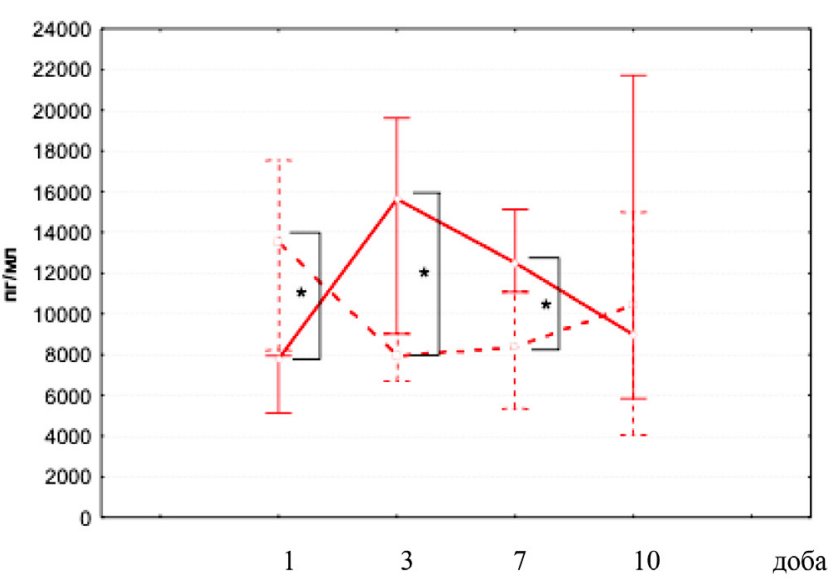

Рис. 1. Індукована ЛПС продукція ІЛ-6 МНК периферичної крові хворих на АС підгруп А і Б у динаміці.

Примітки. Тут і на рисунках 2-5:

1. * - відмінності достовірні, $\alpha=0,05$;

2. Пунктирна лінія - підгрупа А; суцільна (безперервна) - підгрупа Б. 
До 10 доби спостерігалося зниження стимуляції та в хворих підгрупи Б, до цього часу їх продукція ІЛ-6 досягала рівня хворих підгрупи А.

При дослідженні продукції ІЛ-8 МНК периферичної крові хворих на АС у підгрупах А і Б відзначалася різноспрямована динаміка продукції ІЛ-8. При оцінці спонтанної продукції ІЛ-8 МНК на початку захворювання (1 доба) продукція ІЛ-8 у підгрупі А була достовірно підвищена відносно показника у хворих підгрупи Б $(\alpha=0,05)$ і склала в середньому 18837 (17804-24486) пг / мл і 3875 (1948-10018) пг / мл відповідно (рис. 2).

Медіана; відрізки: 25-75 \%

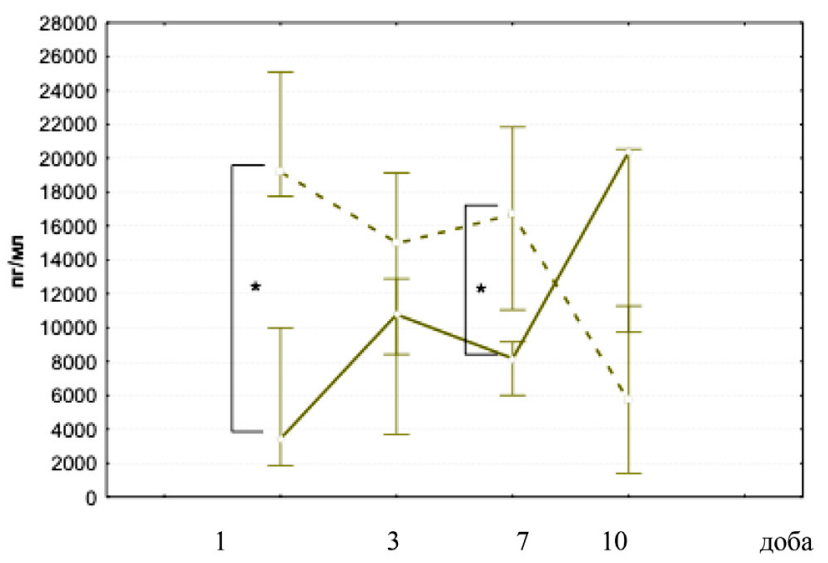

Рис. 2. Спонтанна продукція ІЛ-8 МНК периферичної крові хворих на АС підгруп А і Б у динаміці.

Надалі, до 3 доби перебігу АС, ця різниця зменшилася (статистично вона відсутня на рівні $\alpha$ $=0,05)$, хоча в підгрупі А залишалася тенденція до збереження високого рівня продукції ІЛ-8. На 7 добу спостерігали статистично достовірне $(\alpha=0,05)$ підтвердження цієї тенденції: рівень спонтанної та стимульованої продукції ІЛ-8 у хворих підгрупи А в цьому періоді був вище, ніж в підгрупі Б складало в середньому 16487 (11624-21775) пг / мл і 8189 (6011-9024) пг / мл відповідно.

Між 7 і 10 добою в динаміці сталося “перехрещення” кривих і рівень продукції ІЛ-8 МНК в обстежуваних підгрупах змінився на протилежний. Незважаючи на відсутність статистичної достовірності, слід вказати на наявність тенденції до посилення продукції ІЛ-8 в підгрупі Б і, відповідно, зниження цього показника у хворих підгрупи А.

Характер динаміки профілю індукованої ЛПС продукції ІЛ-8 МНК периферичної крові хворих $з$ АС в підгрупах А і Б був аналогічним спонтанній продукції цього цитокіну.

Продукція ІЛ-10 МНК периферичної крові як спонтанна, так і індукована лігандами TLR на початку (1 доба) захворювання була достовірно вище у хворих підгрупи А (рис. 3).
Медіана; відрізки: 25-75 \%

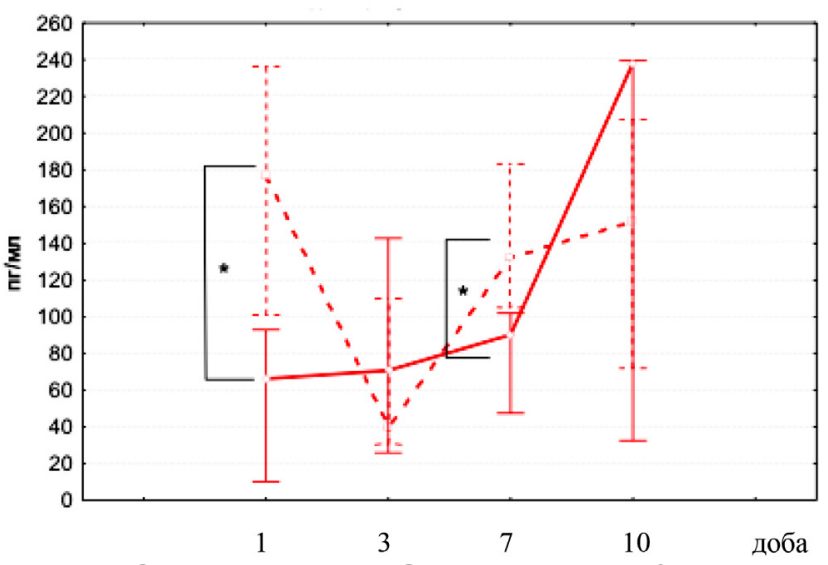

Рис. 3. Індукована ЛПС продукція ІЛ-10 МНК периферичної крові хворих із АС підгруп А і Б у динаміці.

До 3 доби перебігу АС у хворих підгрупи відбувалося зниження спонтанної і індукованої продукції ІЛ-10, в цьому періоді достовірних відмінностей між хворими підгруп А і Б не було. До 7 доби перебігу АС у хворих підгрупи А, порівняно з підгрупою Б, знову відбувалося збільшення продукції ІЛ-10. До 10 доби до цього ж рівня продукції прирівнюються і хворі підгрупи Б, в цьому періоді достовірних відмінностей між обстежуваними підгрупами не спостерігалося.

Таким чином, посилення продукції ІЛ-10 відображає перехід захворювання в репаративну фазу. При цьому хворі підгрупи А, що пербували в стаціонарі (14 \pm 3$)$ ліжко-днів, показують достовірне збільшення продукції ІЛ-10 до 7 доби, тобто у другій половині терміну захворювання. У хворих підгрупи Б відмічено подібну тенденцію, але з урахуванням дещо іншого перебігу АС: підвищення рівня ІЛ-10 спостерігалося до 10 доби захворювання, з урахуванням термінів перебування в стаціонарі $((40 \pm 10)$ ліжко-днів), теж до середини терміну захворювання.

Інтенсивне збільшення рівня будь-якого цитокіну призводило до збільшення його частки в загальному підсумку, одночасно з цим частка "відстаючих” цитокінів зменшилася, тобто слід говорити про усунення балансу в бік цитокінів, рівень яких зростав більш інтенсивно.

3 рисунка 4 видно, що при порівнянні хворих обстежуваних груп насамперед привертає увагу більш висока частка ІЛ-6 в спонтанній продукції цитокінів МНК на 1-7 добу захворювання. При цьому якщо співвіднести ці показники з підгрупою контролю, видно, що тут відбувається чіткий розподіл підгруп.

Показники хворих з підгрупи А в цей період перебувають нижче рівня показників підгрупи контролю - 11,63 $(11,09-14,89) \%$, тоді як показники підгрупи Б достовірно вищі на 3 добу захво- 
Медіана; відрізки: 25-75 \%

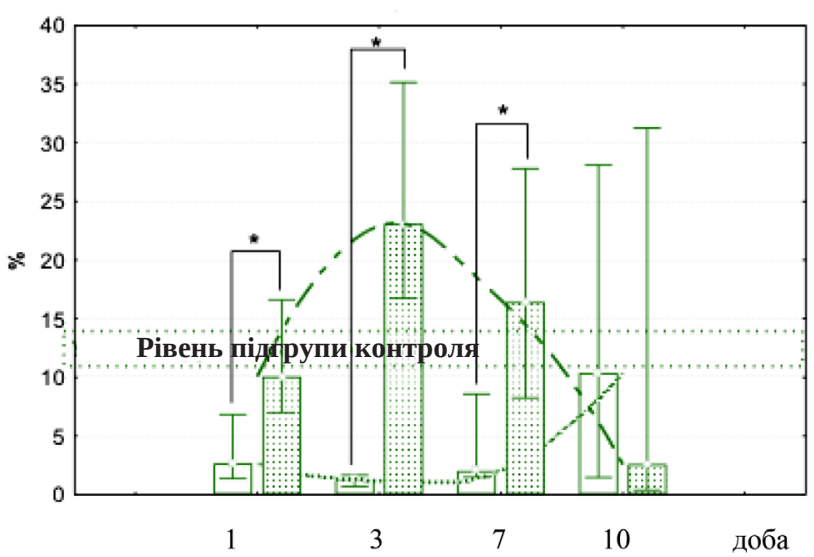

Рис. 4. Частка ІЛ-6 в спонтанній продукції досліджуваних цитокінів МНК периферичної крові хворих на АС в підгрупах А і Б.

рювання або не відрізняються від цього рівня (в 1 і 7 добу).

Порівняння показників балансу ІЛ-6 при стимуляції лігандами TLR також виявляє істотні відмінності між обстежуваними підгрупами. У першу добу захворювання частка ІЛ-6 в підгрупі А достовірно підвищена відносно цього показника у підгрупі Б, однак до 3 доби ситуація змінюється на протилежну і зберігається такою до 7 доби захворювання.

При цьому показники в обох підгрупах були істотно вище рівня здорових донорів із підгрупи контролю протягом усього періоду перебігу хвороби, що не дозволяло використовувати показники умовноздорових донорів із підгрупи контролю для чіткого розподілу підгруп за цим показником.

Впродовж порівнювання обстежуваних підгруп були виявлені істотні відмінності в частці продукування ІЛ-8.

Так, частка ІЛ-8 у спонтанній продукції цитокінів МНК хворих підгрупи А достовірно вища рівня групи контролю на 1-7 добу перебігу АС, тоді як цей показник до 3 доби був достовірно вище, ніж у хворих підгрупи Б (рис. 5).
Медіана; відрізки: 25-75 \%

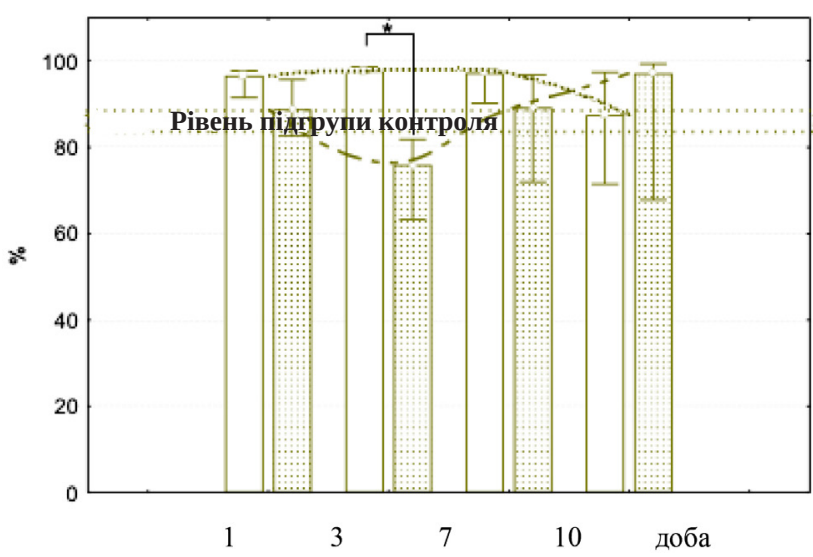

Рис. 5. Частка ІЛ-8 в спонтанній продукції досліджуваних цитокінів МНК периферичної крові хворих 3 АС в підгрупах А і Б.

У цьому випадку також можна встановити критерій розподілу груп на підставі рівня здорових донорів - 86,58 $(80,99-87,24) \%$.

Відповідно, якщо при оцінці балансу частка ІЛ-8 буде $<81$ \%, це може слугувати підставою для менш сприятливого прогнозу перебігу АС і більш тривалого терміну госпіталізації пацієнта з ризиком розвитку ускладнень. Значення показника $>87$ \%, навпаки, дозволяє припустити більш сприятливий прогноз перебігу АС.

Таким чином, у результаті проведених досліджень на даному етапі й описаних в цьому розділі, можна сформулювати новий діагностичний критерій, який дозволяє в ранні терміни розвитку АС прогнозувати його подальший перебіг із виділенням градацій ймовірності розвитку ускладнень (табл. 1).

Так, на 1 добу частка ІЛ-6 в спонтанній продукції досліджуваних цитокінів на рівні $11 \%$ є межею розподілу, по якій слід судити про подальший перебіг АС. На 3 добу перебігу АС можливе уточнення зроблених раніше припущень: значення частки ІЛ-6 та ІЛ-8 в спонтанній продукції цитокінів МНК $<11 \%$ і > 87 \% відповідно, дозволяють припустити подальшу позитивну динаміку перебігу АС.

Таблиця 1. Оцінка показників балансу продукції ІЛ-6 та ІЛ-8 в культурі мононуклеарних клітин периферичної крові для визначення прогнозу перебігу АС і градації ймовірності розвитку ускладнень

\begin{tabular}{||c|c|c|c||}
\hline \hline & $\begin{array}{c}\text { Частка спонтанної продукції } \\
\text { МНК периферичної крові }\end{array}$ & $\begin{array}{c}\text { Сприятливий перебіг, } \\
\text { низька ймовірність розвитку } \\
\text { ускладнень }\end{array}$ & $\begin{array}{c}\text { Несприятливий перебіг, } \\
\text { висока ймовірність розвитку } \\
\text { ускладнень }\end{array}$ \\
\hline \multirow{2}{*}{1 доба } & ІЛ-6 (\%) & $<11 \%$ & $>11 \%$ \\
\hline \multirow{2}{*}{3 доба } & ІЛ-6 (\%) & $<11 \%$ & $>15 \%$ \\
\cline { 2 - 4 } & ІЛ-8 (\%) & $>87 \%$ & $>81 \%$ \\
\hline
\end{tabular}


Підвищення частки ІЛ-6 у спонтанній продукції >15 \% з одночасним зниженням частки ІЛ-8 $<81$ \% погіршує прогноз перебігу АС із високою ймовірністю розвитку ускладнень.
Всі ці дані корелюють з результатами, отриманими при дослідженні рівня цитокінів у сироватці крові пацієнтів на АС (табл. 2).

Таблиця 2. Вміст цитокінів у сироватці крові хворих на абдомінальний сепсис

\begin{tabular}{|c|c|c|c|}
\hline \multicolumn{2}{|c|}{ Вміст цитокінів } & \multirow{2}{*}{$\begin{array}{c}\text { Підгрупа А } \\
\text { медіана (25-75 \%) } \\
16,5(12,4-20,5)\end{array}$} & \multirow{2}{*}{$\begin{array}{c}\text { Підгрупа Б } \\
\text { медіана (25-75 \%) } \\
17,3(9,2-25,4)\end{array}$} \\
\hline ФНО $\alpha$ (пг/мл) & 1 доба & & \\
\hline & 6 доба & $17,3(14,9-19,7)$ & $14,2(11,3-17,2)$ \\
\hline \multirow[t]{2}{*}{ ІЛ-6 (пг/мл) } & 1 доба & $8,2(6,1-10,3)$ & $313,29 *(60,9-565,7)$ \\
\hline & 6 доба & $54,4(0-108,7)$ & 31,81 (1,01-6,61) \\
\hline \multirow[t]{2}{*}{ ІЛ-8 (пг/мл) } & 1 доба & $16,1(1,2-30,9)$ & $66,7 *(54,1-79,4)$ \\
\hline & 6 доба & $38,5(10,4-66,7)$ & $32,66(26,3-39,03)$ \\
\hline \multirow[t]{2}{*}{ ІЛ-10 (пг/мл) } & 1 доба & $2,3(0,63-3,93)$ & $2,2(0,61-3,79)$ \\
\hline & 6 доба & $0,4(0,16-0,64)$ & $0,02(0-0,04)$ \\
\hline
\end{tabular}

Примітка: *_ відмінності між підгрупами достовірні, $\alpha=0,05$.

У культурі in vitro спостерігалося пригнічення продукції як про-, так і протизапальних цитокінів MHК здорових донорів підгрупи контролю, стимульованих лігандами TLR2 і TLR4.

Висновки. 1. Вивчення в динаміці (1-10 доба) профілю цитокінів (ФНО, ІЛ-6, ІЛ-8, ІЛ-10), що продукуються мононуклеарними клітинами периферичної крові спонтанно і під впливом лігандів TLR, дозволило виділити серед обстежуваних хворих дві підгрупи: сприятливий перебіг АС, з одужанням протягом (14士3) ліжко-днів (спонтанна й індукована продукція IЛ-8 знижувалося до 10 доби, а індукована лігандами TLR продукція протизапального цитокіну IЛ-10 підвищувалася до 7 доби), та неспри-

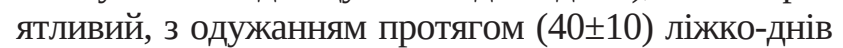

\section{СПИСОК ЛІТЕРАТУРИ}

1. Бенедикт В. В. Гострий поширений перитоніт. Патогенетична корекція післяопераційних моторно-евакуаторних порушень тонкої кишки / В.В.Бенедикт // Український журнал хірургіï. - 2011. - № 4. - С. 89-94.

2. Бойко В. В. Синдром системної запальної відповіді (SIRS). Сепсис: [метод. рекомендації] / В. В. Бойко, С. I. Макеєв, М. М. Голобородько. - Х. : ХНМУ, 2010. - 14 с.

3. Munez E. Microbiology of surgical site infections in abdominal tract surgery patients / E. Munez, A. Ramos, T. A. Espejo // Cir. Esp. - 2011. - Vol. 89 (9). - P. 606-612.

4. Anthony D. Statistics for health? Life and social sciences (підвищення спонтанного й індукованого лігандами TLR продукції IЛ-6 з 3 до 10 доби та індукованої лігандами TLR продукція цитокіну IЛ-10 до 10 доби).

2. У хворих із сприятливим перебігом захворювання баланс прозапальних цитокінів збільшувався за рахунок ІЛ-8, а у хворих з несприятливим перебігом - IЛ-6, що може слугувати прогностичним критерієм перебігу і наслідків АС, тоді як оцінка показників ФНО виявилася не інформативною.

Перспектива подалыших досліджень. Актуальним напрямком є вивчення можливості лікувального впливу, спрямованого на корекцію функціональної активності TLR у хворих з AC, антибіотиків у комплексній медикаментозній консервативній терапії.

/ D. Anthony. - Ventus Publishing Aps, United Kingdom. University of Essex, 2011. - 292 p.

5. Gheorghe A. West Midlands Research Collaborative; ROSSINI Trial Management Group. Systematic review of the clinical effectiveness of wound - edge protection devices in reducing surgical site infection in patients undergoing open abdominal surgery / A. Gheorghe, M. Calvert, T. D. Pinkney // Ann. Surg. - 2012. - Vol. 255 (6). - P. 1017-1029.

6. Yoneyama M. Recognition of viral nucleic acids in innate immunity / M. Yoneyama, T. Fujita // Rev. Med. Virol. - 2010. No. 20 (l). - P. 4-22. 


\section{REFERENCES}

1. Benedykt, V.V. (2011). Hostryi poshyrenyi perytonit. Patohenetychna korektsiia pisliaoperatsiinykh motorno-evakuatornykh porushen tonkoi kyshky [Acute peritonitis. Pathogenetic correction of postoperative motor-evacuation disorders of the small intestine]. Ukrainskyi zhurnal khirurhii - Ukrainian Journal of Surgery, 4, 89-94 [in Ukrainian].

2. Boiko, V.V., \& Makeiev, S.I., \& Holoborodko, M.M. (2010). Syndrom systemnoi zapalnoi vidpovidi (SIRS). Sepsys: [Systemic inflammatory response syndrome (SIRS). Sepsis]. Kharkiv [in Ukrainian].

3. Munez, E., Ramos, A., \& Espejo, T.A. (2011). Microbiology of surgical site infections in abdominal tract surgery patients. Cir.
Esp., 89 (9), 606-612.

4. Anthony, D., (2011). Statistics for health? Life and social sciences. Ventus Publishing Aps, United Kingdom. University of Essex.

5. Gheorghe, A., Calvert, M., \& Pinkney, T.D. (2012). West Midlands Research Collaborative; ROSSINI Trial Management Group. Systematic review of the clinical effectiveness of wound - edge protection devices in reducing surgical site infection in patients undergoing open abdominal surgery. Ann. Surg., 255 (6), 1017-1029.

6. Yoneyama, M., \& Fujita, T. (2010). Recognition of viral nucleic acids in innate immunity. Rev. Med. Virol., 20 (1), 4-22.

Отримано 22.11.2019

\title{
ASSESSMENT OF THE SPONTANEOUS AND INDUCED BY LIGANDS TLR2 AND TLR4 OF PRODUCTS OF INFLAMMATORY AND ANTIINFLAMMATORY CYTOKINES AT PATIENTS WITH ABDOMINAL SEPSIS
}

\begin{abstract}
The aim of the work: to study in dynamics synthesis inflammatory and antiinflammatory cytokines in patients with abdominal sepsis and their balance for assessment of the predictive importance.

Materials and Methods. 36 patients with abdominal sepsis are surveyed and operated. All patients were divided into 2 subgroups of comparison. The subgroup A included patients on the AS who were in a hospital (14 \pm 3 ) bed days. In this subgroup the optimum option

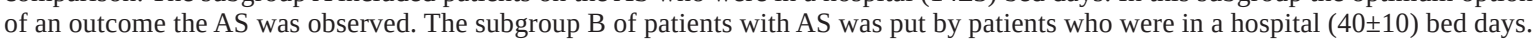
In this group development of a number of complications AS is noted. As group of control served the group of almost healthy donors. Results and Discussion. Studying in dynamics (1-10 days) of a profile of cytokines (TNF, IL-6, IL-8, IL-10) which are produced by mononuclear cells of peripheral blood of patients with AS spontaneously and under the influence of TLR ligands, allowed to distinguish from the studied sick two subgroups: a favorable outcome the AS, with recovery during $(14 \pm 3)$ bed days (the spontaneous and induced products - l-8 decreased by 10 days, and the products induced by ligands TLR antiinflammatory to cytokine l-10 raised by 7 days), and adverse, with recovery during $(40 \pm 10)$ bed days (increases in the spontaneous and induced by ligands TLR of products SILT - 6 with 3 by 10 days and TLR induced by ligands products to IL-10 cytokine - up to 10 days). In patients with the favorable course of a disease the balance of pro-inflammatory cytokines increased for the account IL-8, and patients with the adverse course have IL-6 that the AS can serve as predictive criterion of an outcome and consequences while assessment of indicators of FNO was not informative.
\end{abstract}

Key words: abdominal sepsis; Toll-like receptors; cytokines.

\author{
В. П. ПОЛЕВОЙ, С. П. ПОЛЕВАЯ, Ю. Н. СОЛОВЕЙ, Н. Н. СОЛОВЕЙ
}

ВГУЗ Украины “Буковинский государственный медицинский университет”

\section{ОЦЕНКА СПОНТАННОЙ И ИНДУЦИРУЕМОЙ ЛИГАНДАМИ ТLR2 И ТLR4 ПРОДУКЦИИ ПРО- И ПРОТИВОВОСПАЛИТЕЛЬНЫХ ЦИТОКИНОВ У БОЛЬНЫХ С АБДОМИНАЛЬНЫМ СЕПСИСОМ}

\footnotetext{
Цель работы: изучить в динамике синтез про- и противовоспалительных цитокинов у больных с абдоминальным сепсисом (АС) и их баланс для оценки прогностической значимости.

Материалы и методы. Обследовано и прооперировано 36 больных с абдоминальным сепсисом. Все больные были разделены

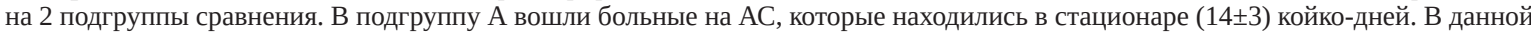
подгруппе наблюдался наиболее благоприятный вариант исхода АС. Подгруппу Б больных на АС составили пациенты, которые находились в стационаре $(40 \pm 10)$ койко-дней. В этой группе отмечено развитие ряда осложнений АС. Группой контроля служила группа практически здоровых доноров.

Результаты исследований и их обсуждения. Изучение в динамике (1-10 сутки) профиля цитокинов (ФНО, ИЛ- 6, ИЛ- 8, ИЛ10), которые продуцируются мононуклеарными клетками периферической крови больных с АС спонтанно и под воздействием лигандов TLR, позволило выделить среди исследуемых больных две подгруппы: благоприятный исход АС, с выздоровлением в

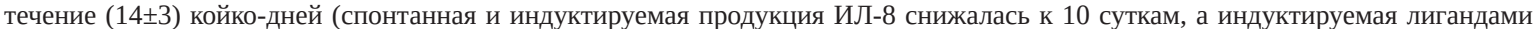
TLR продукция противовоспалительного цитокину ИЛ-10 повышалась к 7 суткам), и неблагоприятный, с выздоровлением в течение $(40 \pm 10)$ койко-дней (повышения спонтанного и индуктируемого лигандами TLR продукции ИЛ-6 с 3 к 10 суткам и индуктируемой лигандами TLR продукция цитокину ИЛ-10 до 10 суток). У больных с благоприятным течением заболевания баланс прововоспалительных цитокинов увеличивался за счет ИЛ-8, а у больных с неблагоприятным исходом - ИЛ-6, что может служить прогностическим критерием исхода и последствий АС, в то время, как оценка показателей ФНО оказалась не информативной.
}

Ключевые слова: абдоминальный сепсис; Toll-подобные рецепторы; цитокины. 